\title{
Editing Hamlet for Performance
}

\section{Abigail Rokison-Woodall}

\section{(2) OpenEdition \\ Journals}

Electronic version

URL: https://journals.openedition.org/shakespeare/6059

DOI: 10.4000/shakespeare.6059

ISSN: 2271-6424

\section{Publisher}

Société Française Shakespeare

\section{Electronic reference}

Abigail Rokison-Woodall, "Editing Hamlet for Performance", Actes des congrès de la Société française Shakespeare [Online], 39 | 2021, Online since 22 June 2021, connection on 17 February 2023. URL: http://journals.openedition.org/shakespeare/6059 ; DOI: https://doi.org/10.4000/shakespeare.6059

This text was automatically generated on 17 February 2023.

All rights reserved 


\title{
Editing Hamlet for Performance
}

\author{
Abigail Rokison-Woodall
}

1 Using Hamlet as a focus, this paper examines the history of "Acting" editions of Shakespeare plays from the $17^{\text {th }}$ century to the present day, arguing that many of these texts were never intended for use in the preparation of a production, and that others, produced with actors and directors in mind, no longer meet the needs of contemporary performers. Noting the tendency of theatre practitioners in the $21^{\text {st }}$ century to make use of scholarly editions of the plays, rather than performance ones, it explores the ways in which these texts too may fail to serve the demands of a modern rehearsal room. Arguing that there is a need to re-think the need and nature of the "Acting" edition, it explains choices made by the new Arden Performance series, launched in 2017, of which I am one of the general editors and editor of Hamlet and A Midsummer Night's Dream. It discusses ways in which this series seeks to address some of the main challenges faced by actors and directors mounting a Shakespearean production.

\section{"Acting" editions}

2 The concept of editions of Shakespeare closely tied to performance is not new. The first versions of Shakespeare published, often in Quarto form, frequently advertise their status as souvenirs of performances, ${ }^{1}$ and the Quartos of King Lear and Pericles were, soon after their publication, apparently put to use by at least one rival company. ${ }^{2}$ In 1661 there even appeared an abbreviated version of A Midsummer Night's Dream, dating from the interregnum (c.1646) and specifically advertised as a text that had been successfully acted by amateurs as well as professionals: "The Merry conceited Humors of Bottom the Weaver./ As/It hath been often publikely Acted by some of his Majesties $\mathrm{Co} / m e d i a n s$, and lately, priuately, presented,/ by several Apprentices for their harmless recreation, with Great Applause." A more consistent pattern for the production of acting editions emerges a little later in the Restoration with the appearance of what are now known as "Players' Quartos", ${ }^{3}$ editions based on late $17^{\text {th }}$ and early $18^{\text {th }}$ century productions of the plays. 
These acting editions sought, for the most part, to put the play, as acted by a particular theatre company, on the page. Some of the early acting editions, like William Davenant's Law Against Lovers (adapted from Measure for Measure and Much Ado About Nothing), Macbeth, and The Tempest (written with John Dryden) were essentially adaptations, severely cut and substantially re-written; as Michael Dobson notes, they did not even feature Shakespeare's name on their title pages. ${ }^{4}$ However, Davenant's The Tragedy of Hamlet Prince of Denmark, printed in 1676, is quite different in form. The text is advertised as presenting the play "As It is now Acted at his Highness the Duke of York's Theatre", but what is actually provided is a full text of the play based on the Second Quarto (Q2), marked up to indicate the performance text. The introductory matter tells the reader:

This Play being too long to be conveniently Acted, such places as might be least prejudicial to the Plot or Sense, are left out upon the Stage: but that we may no way wrong the incomparable Author, are here inserted according to the Original Copy with this Mark ".

William Shakespeare, The Tragedy of Hamlet, Prince of Denmark, As it is now Acted at his Highness the Duke of York's Theatre, London, 1676, sig. A4r.

The intention seems to be simultaneously to privilege the stage and the author (who is here named on the title page). However, not all of the lines of the "incomparable author" make it into the text intact. As Peter Holland has discussed in "Theatre Editions", which studies cuts and changes made to the text of Hamlet in theatrical editions, a number of lines are silently revised and words altered, simply to make them more accessible or tasteful, without any indication to the reader. ${ }^{5}$

5 The next major acting edition of Hamlet: the Wilks-Hughes text of 1718, "As It is now Acted by his Majesty's Servants", which "became the standard performance edition, acting text, and basis for promptbooks for over a century", ${ }^{6}$ has a similar layout to the Davenant edition, and contains a similar note: "The Play being too long to be acted upon the Stage, such Lines as are left out in the Acting, are marked thus '." The text follows many of the Davenant/Betterton alterations, but is more assiduous about including the cut lines. As Holland asserts, these texts seem "aimed at a reader but one who is posited to be interested in differentiating between the performance-text and the text Shakespeare wrote."

6 However, the nature of the acting edition changed in 1773-4 with the publication of the first complete acting edition of Shakespeare's plays - Bell's Acting Edition - in nine volumes with notes by Francis Gentleman. Bell's edition published the plays, "As they are now performed at the Theatres Royal in London; Regulated from the Prompt Books of each House By Permission", 9 the Hamlet text being that performed at the Theatre Royal, Covent Garden. Bell's text saw one of its principal tasks as being to preserve, in print, the supposedly "superior" versions of Shakespeare as performed in the theatre, which had been corrected of "faults" that could "justly be attributed to the loose, quibbling, licentious taste of his time." 10 Contemporary theatres, maintained the editors, "especially of late, have been generally right in their omissions."11

7 Some lines are simply cut. In other cases the plays are substantially altered - heavily cut, rearranged and re-written - usually with no indication of what has been changed or removed. Charles Shattuck asserts that with this publication "the acting edition, cut for performance, became regularized and popular in the profession", Bell's editions being widely used "for promptbook-making for two or three decades", before being replaced by John Philip Kemble's in the 1790 s and then, in the $19^{\text {th }}$ century by the 
“'standard' acting editions" of Mrs Inchbald, Oxberry, Cumberland, Hinds English Stage, Lacy, Kean and Irving. ${ }^{12}$ The popularity of these editions is attested to by the successive versions which were produced..$^{13}$ Each of these "standard" acting editions contained the texts of the plays as they were said to have been performed at one of the major theatres.

8 A number of the $19^{\text {th }}$ century editions contain quite elaborate stage directions, recording the action of the productions on which they are based. Some also contain notes on other aspects of staging, seemingly designed to help a director with mounting a production of the play. Both Cumberland's edition of $1826^{14}$ and Charles Kean's edition of $1859^{15}$ provide full and detailed lists of costumes for each of the characters, information about exits, entrances and staging positions and a note which explicitly puts the reader in the position of an actor:

STAGE DIRECTIONS.

R. H. means Right Hand; L. H. Left Hand; U. E. Upper Entrance; R. H. C. Enters through the Centre from the Right Hand; L. H. C. Enters through the Centre from the Left Hand.

Relative Positions of the Performers when on the Stage.

R. means on the Right side of the Stage; L. on the Left side of the Stage; C. Centre of the Stage; R. C. Right Centre of the Stage; L. C. Left Centre of the Stage.

The reader is supposed to be on the Stage, facing the audience. ${ }^{16}$

As well as suggesting when and where actors should move, Kean's edition also provides regular commentary notes, glosses of difficult words and phrases, many of which are drawn from earlier "scholarly" editors. This edition gets closest to something that might be considered genuinely useful by someone wishing to mount a production of Hamlet, providing the actor with some assistance in interpreting the text.

As Shattuck notes, however, although further acting editions of individual plays were published in the late $19^{\text {th }}$ and early $20^{\text {th }}$ centuries, "as the fashion in production became increasingly individual, even idiosyncratic, few of these actors' editions [. . .] were much used". ${ }^{17}$ Professional productions began to use fully published texts of the plays, often cut up and pasted into larger prompt-books for easy annotation. Although it remained profitable for Henry Irving's name to be attached to a large, decorative edition of the plays in 1895, this edition was not, as editor Frank A. Marshall makes clear, "an acting edition of Shakespeare". ${ }^{18}$ Although designed to be of use to "those who read Shakespeare aloud" ${ }^{19}$ as a multi-volume edition, the texts are too large and heavy for use in rehearsal and too elaborate in their presentation and binding to be cut up by those wishing to prepare a prompt-book. Nevertheless, the introduction does include material on features of the text which are designed to aid an "actor or speaker of the verse" in his/her pronunciation and scansion, ${ }^{20}$ which is not a feature of any other acting edition discussed here. The editors make a point, for example, of instructing the reader that:

words ending in ion, as "action", "confusion" \&c, must not be pronounced in the usual slovenly way in vogue nowadays, as if they were spelt "acshun", "confushun", but as if the ion were the two last syllables of a dactyl. If attention is not paid to this rule, some of the lines of Shakespeare will be curtailed of one syllable where the poet did not intend it. ${ }^{21}$

11 This interesting note shows concern for an adherence to the metrical structure of the verse line; however, it is potentially misleading. In Hamlet, for example, only five 
instances of ion endings require pronunciation as two syllables in order for the verse line to scan ${ }^{22}$ whilst in other, far more numerous, places this would result in an extra, un-metrical syllable which would disrupt the metre. ${ }^{23}$

The editors also explain their "treatment of words ending in ed" which they claim is deliberately "slightly different from that employed by most modern editors", with an " $d$ " indicating elision and an "ed" indicating that the final syllable should be pronounced in both verse and prose sections of the text. ${ }^{24}$ In verse sections this notation is fairly easy to follow, though most modern editors use an accented "èd" to indicate the pronunciation of the final syllable. However, the notion that such a distinction might also function in the prose sections of the Folio text, with "the final ed [...] generally elided when the speaker is speaking familiarly" and pronounced elsewhere ${ }^{25}$ is extremely difficult to substantiate. In 2.2, for example, in Hamlet's conversations with Polonius and Rosencrantz and Guildenstern, we find the two forms used interchangeably in the Folio, with no obvious indication of any change in tone:

HAMLET. I sir, to be honest as this world goes, is to bee

one man pick'd out of two thousand. (F.TLN. 1215-16)

old men haue gray Beards; that their faces are wrink-

led

(F.TLN.1235-6)

what haue you my good friends, deserued at the hands of Fortune

(F.TLN.125-6)

Are they so follow'd? (F.TLN.1382)

Acting Editions representing the play "as performed" continue to be published to this day. Stephen Unwin produced editions of Shakespeare plays in the versions performed by the English Touring Theatre under his artistic directorship in the early $21^{\text {st }}$ century, containing the cuts and the punctuation used in his productions. ${ }^{26}$ The Donmar Warehouse have published texts of their Hamlet (2009), King Lear (2011) and Coriolanus (2013); and Josie Rourke's script for her production of Much Ado About Nothing in 2011 was published by Nick Hern. As Holland has discussed, these texts rarely make explicit their cuts, redistribution of lines or minor re-writings. ${ }^{27}$ They are, essentially, souvenirs of a particular production, as Josie Rourke makes explicit in her Introduction to Coriolanus: "We publish the text in the hope that it may be of interest to those who saw the production, or to a reader curious about the choices we made with the play. This is not an academic edition of Coriolanus; nor is it a blueprint for any other production." ${ }^{28}$

The most famous $20^{\text {th }}$-century acting editions, not only of Shakespeare, but of many other plays in the canon, are those published by Samuel French. These acting editions are certainly aimed at actors and directors and intended for use in the preparation of productions. The edition of Hamlet, published in 1964 with notes by George Skillan, states that it "closely follows the version prepared by Sir Johnston Forbes-Robertson for his revival at the Lyceum Theatre", ${ }^{29}$ a production which had occurred in the late $19^{\text {th }}$ century. There is some compression of the text, but for the most part, just as in the early $17^{\text {th }}$ - and $18^{\text {th }}$-century editions, the full text is given, with suggested abridgements marked with square brackets.

The "French's Acting edition" supplies very little for either the director or the actor in the way of interpretation. A plan of the stage is provided, together with a full list of 
props and furniture for each scene and a lighting plot. The text is presented in the lefthand column, whilst the right-hand column contains detailed instructions for blocking and movement, as well as instructions about delivery:

[4] An indication of apprehension in the manner of BERNARDO in respect of the apparition of the KING must be registered from the outset. BERNARDO'S 'Who's there?' should not be given as an ordinary challenge, but as though the man had superstitious dread. ${ }^{30}$

The text is followed by a commentary on each scene, which provides a step-by-step analysis as well as a glossary of words and phrases.

In many respects this text is contradictory. It assumes no creative or imaginative ability whatsoever on the part of the director or actor, and yet the technical language in which the instructions are given presupposes some significant theatrical knowledge and vocabulary: "Fig. 3. An inset scene - which can be braced, and flanked by Tabs or Traverse J and backed by Traverse F, which is used in all inset scenes, and should be of a neutral tone upon which different effects of light may be obtained." ${ }^{31}$ One wonders who this text is for. Certainly Holland, writing in two different publications, assumes that the main users of such texts would be amateur actors: "Everything is minutely prescribed, a theatre of the mind that can be translated confidently to any amateur performance in the world without the slightest need to investigate anything in rehearsal other than replication of the instructions"; 32 "their commentary aims to be prescriptive for future - usually amateur - performance." ${ }^{33}$

18 However, there is also some evidence that French's Acting editions were used by regional professional theatre companies in the 1960s. In their respective biographies, actors Glyn Idris Jones and James Hayes both refer to the common use of these editions, Hayes remarking that "the scripts for each play we rehearsed were hired from a company called Samuel French's in London [...] referred to as French's Acting Editions" 34 whilst Jones comments of director Lionel Hamilton at Northampton, "Even if they lacked imagination, his productions were clean, professional and at least he didn't always abide by French's acting editions", citing an anecdote about "a director, who looking at his French's script says to his actor, 'You move downstage here', to which the actor replies, 'I am downstage', to which the director says, 'I don't care, it says here you move down-stage', and the actor falls into the orchestra pit." 35

Whilst in the mid- $20^{\text {th }}$ century it may have been the case that some amateur, and even professional repertory companies were still content merely to reproduce the staging of a historic Shakespearean production, it is clear that most contemporary amateur, and indeed school drama groups, are as keen as professional ones to put their own stamp on a production, coming up with their own ideas about setting, props, staging and interpretation, rather than having these things dictated to them.

None of the acting editions cited above meets the complex needs of a contemporary rehearsal room. Most provide either limited to no glossing of words, without assisting the actor in interpreting Shakespeare's language; they often include prescriptive stage directions reflecting the staging of just one particular production. It is no surprise, therefore, that such acting editions have fallen out of favour and are no longer used by those preparing a production. 


\section{The scholarly edited text in the theatre} rooms and bore the RSC's endorsement throughout the 1980s and 90s, and, in its updated form from 2005 onwards, that of the National Theatre. Its use by actors is mainly due to its convenient compact size and uncluttered text, as well as its relatively low cost. However, one of the major drawbacks of the New Penguin for use by actors is the fact that the glossary notes are at the back, meaning that it takes some time to find the corresponding word definition. Stanley Wells defends this decision on the basis that "it is easier for actors to use, both because it allows more text to the page and because it leaves more room for scribbling in the margins." ${ }^{36}$ Whilst this is certainly true, an actor in a rehearsal room needs to be able to access a definition quickly and conveniently. In most other scholarly editions, the glossary notes are at the bottom of the page, which, whilst easier to access, can also make a corresponding gloss difficult to find with speed. These notes are also often long and quite cumbersome. As the RSC's artistic director Gregory Doran commented, when talking about texts for use in rehearsal, "There are just too many footnotes in the Arden, and they're just too literary." ${ }^{37}$

As a consequence, most contemporary professional productions currently use either photocopied texts of one of the major published editions, without the footnotes, or specially typed-up versions based on published or online texts. One of the main reasons for using a typed-up or photocopied text without footnotes is that directors want to make the text as large as possible, and to avoid cluttered notes. However, such texts obscure from actors the existence of textual variants and provide them with no assistance with glossing difficult words, something that serves to disempower actors, many of whom will inevitably consult another scholarly text.

As detailed in Shakespearean Verse Speaking, actors working with modern edited texts often run up against editorial decisions which may affect their interpretation. Although features such as lineation and punctuation are often regarded by editors as "accidentals", they are afforded considerable weight by theatre practitioners, who frequently regard them as indicative of the pace of a scene, the desired location of pauses, and the mood of a character. ${ }^{38}$ The late Peter Hall describes the lineation of the text as "absolutely crucial to the rhythm and thus the understanding of the scene." ${ }_{39}$ However, editorial principles for decisions about lineation and punctuation vary between editions and are not always made explicit, being frequently consigned to the discursive notes at the beginning or end of the text. One of the most problematic issues is actors' interpretation of short lines in the Shakespearean text, and the impact of editorial practice on their delivery. The most common assertion about short lines is that they imply a pause in the dialogue roughly equivalent to the number of missing syllables. According to Hall, with a half line - "The silence is written as surely as it is in Pinter"; ${ }^{40}$ Patsy Rodenburg states that actors should actually: "count the silent iambics before they speak." ${ }^{11}$ This becomes particularly problematic in cases of ambiguous lineation, where three short lines succeed one another, each pair appearing to have an equal metrical claim to linkage. Most editions (the Oxford Shakespeare, New Oxford Shakespeare, and RSC editions excluded) $)^{42}$ choose to link one pair of lines in favour of the other and leave one line unconnected. However, the principles for deciding which lines to link vary. In the following example, Arden 3 sets the lines like this:

Actes des congrès de la Société française Shakespeare, 39 | 2021 
HAMLET. Saw, who?

HORATIO. My lord, the King your father.

HAMLET. The King my father?

Arden 3, ed. Thompson and Taylor. ${ }^{43}$

(1) possible choices available to the actor are not always immediately apparent. Indeed, many actors may not be aware of the existence of multiple texts of a particular play, which may offer different choices in terms of words and even structure. Most scholarly editions of Hamlet are based on a mixture of the Second Quarto (Q2) and Folio (F) texts, ${ }^{45}$ with editors using a main copy-text (either $Q$ or F) and then selecting their preferred variants. For Arden 3, Ann Thompson and Neil Taylor took the step of editing all three texts separately, on the basis that "the three texts are remarkably distinct entities" 46 but whilst this might work for a reader, it would not work for an actor or director, who needs to be able to create a single performance text. Most scholarly editions provide details of textual variants (even those which do not offer a viable, playable alternative) as a running code at the bottom of the page, referred to by Tom Berger as the "band of terror". ${ }^{47}$ Many actors, and even some directors, do not know how to interpret this code, and hence are unaware of the textual options available; they tend to rely predominantly on the choices made by the editor of the edition at their disposal.

The Introductions to editions are rarely copied and distributed to actors with the text. This is partly because of their length, but also because they are perceived to contain information that is not directly relevant to an actor, and in some cases may seem positively unhelpful. The question of what actors and directors might want or need in terms of introductory material is one that has not been explored in any detail. Many directors comment anecdotally on their voracious reading of scholarly introductions as a way of discovering as much as possible about a text. ${ }^{48}$ When consulted on what they feel that actors need or want, however, the responses vary. In interviews consulted for Shakespeare Bulletin in 2016, directors Trevor Nunn, Gregory Doran and Lucy Bailey, alongside actor Simon Russell Beale, were consulted about what they felt a performance edition might usefully provide in terms of introductory material. Nunn, who comes from an older generation of directors, was very open about his concerns that the provision of a production history and information about source material and textual variants might contribute to the erosion of directorial authority, already under threat due to the presence of i-pads in the rehearsal room. ${ }^{49}$ Doran and Bailey both expressed a desire to know about source materials, production history, historical context and variant texts, and seemed open to the idea of a text that might provide actors as well as directors with such information. ${ }^{50}$ However, whilst all three directors expressed their own interest in the performance history of a play that they are directing, Bailey was doubtful as to whether actors would want to know about previous productions, ${ }^{51}$ and Simon Russell Beale was adamant that whilst source material, variant texts and historical context were all of interest, production history was "a no-

Actes des congrès de la Société française Shakespeare, 39 | 2021 
no". He provided the example of Donald Sinden as Malvolio in John Barton's production of Twelfth Night at the RSC in 1969, who famously entered in 3.4, looked at the sundial and at his pocket watch, the two of which differed, and corrected the sundial, Beale stating "I could never repeat it, and I could never think of something as good as that." 52 Actors are often resistant to a performance history, since they fear, as Beale did, that it might threaten their creativity by limiting their options.

As can be seen from the foregoing discussion, there are a number of features of modern scholarly edited texts that do not serve the needs of actors and directors and may prove misleading or restrictive. The time is surely ripe for rethinking the nature of the acting edition so that it is informed by modern textual scholarship, but un-cluttered by extensive bibliographical and academic material. This new edition could respond to the needs of actors, providing them with clear, straightforward, easily accessible glossing; visible, performatively viable, textual variants; guidance regarding the pronunciation of unusual or obscure words and the metrical scansion of lines. Far from being prescriptive, such an edition would not be linked to the staging of any past production or to a previously performed version of the text. It would dispense with the weighty introductory material which actors and directors could research elsewhere, and would instead provide its users with a clear, straightforward indication of editorial principles and information relating to the relevant areas of the text.

This rigorous academic and theatrical experiment is now underway in the form of the Arden Shakespeare Performance Editions, whose general editorial team comprises two Shakespeare academics, Michael Dobson and Abigail Rokison-Woodall, and actor Simon Russell-Beale. The editions use as their copytext the Arden 3 editions, since these are prepared with scrupulous attention, informed by current textual and historical scholarship; however, they are reannotated and redesigned with the needs of actors and directors in mind. One of the main elements of redesign is the use of facing-page notes. Unlike other scholarly editions that place glossary notes and textual variants either at the bottom of the page or at the back of the book, these editions place them on the recto, immediately opposite the line to which they refer. This solution provides an uncluttered text and space to write notes and record blocking, whilst being easier to access. The facing page notes are divided into two columns, with definitions appearing on the left, and textual variants and other key textual commentary on the right.

The use of the text of the Arden 3 editions is largely uncomplicated. However, in the case of Hamlet it is more problematic, as the "standard" Arden 3 Hamlet is based on Q2, with the F text printed separately; ${ }^{53}$ it uses F variants only in cases where Q2 is widely considered to be erroneous or misleading. For example, it has Polonius utter, "Neither a borrower nor a lender boy" (1.3.74) rather than F's "Neither a borrower nor a lender be", which is more often heard in the theatre. The Arden Performance edition of Hamlet, however, uses $\mathrm{F}$ variants in the main text where they are commonly found in performance (noting the $Q$ variant on the facing page), including the common $F$ variant "he" where Q2 uses "'a". In addition, rather than consign F-only passages, many of which are regularly used in performance, to an appendix, as do many editions based on Q2, the Performance edition includes all passages present only in F, on the basis that it is easier for actors and directors to remove such passages than add them onto a text on which they are working. Any passages which are particular to either F or Q2 are marked with square brackets, making them easy to identify. 
31 A further alteration made to the Arden 3 copytext, in the case of all editions, is to the lineation of short lines, as discussed above. Where the metrical connection between lines seems unambiguous, the Performance editions follow George Steevens and editors since $1793^{54}$ in indenting the second part of the line to make visually explicit the fact that they amount to one metrical line. However, the Performance editions differ from most other editions in the representation of three consecutive short lines. Rather than printing them as one shared and one short line, they seek to make the ambiguous metrical connection ${ }^{55}$ apparent by indenting both the second and third portions of the line and adding a facing-page note ("ambiguous metrical connection"):

HAMLET. Saw, who?

HORATIO. My lord, the King your father.

HAMLET. $\quad$ The King my father?

32 In cases where the middle line might be regarded as an interjection, or indicative of overlapping dialogue $\mathrm{e}^{56}$ as in this example from Hamlet, the note makes such a possibility explicit:

HAMLET. [...]

A cut-purse of the Empire and the rule,

That from a shelf the precious Diadem stole

And put it in his pocket.

GERTRUDE. No more.

HAMLET. A King of shreds and patches,

(Ham. 3.4.101-103)

33 Gertrude's "No more" may be seen as an interjection, overlapping with Hamlet's lines. As discussed in detail in Shakespearean Verse Speaking, such overlapping dialogue could have been easily indicated to an Early Modern actor playing Hamlet from a cued part if he were given a continuous speech, and if the actor playing Gertrude had the cue-line "in his pocket". ${ }^{57}$ Where a series of short lines (more than three) succeed one another and the metrical connection is ambiguous, all lines are aligned to the left hand margin, as in The New Oxford Shakespeare: The Complete Works and The RSC Shakespeare, and a note is added on the facing page.

34 The decision to lineate ambiguous metrical structures in this way is partly motivated by evidence that suggests that early modern actors, working from cue-parts, would not have been able to see the metrical connections between their lines and those of other actors. They are thus unlikely to have distinguished between full-line cues and shortline cues in their delivery. ${ }^{58}$ Unlike many editions, in which editorial notes on lineation are unpublished or consigned to an appendix, the Performance editions explain these principles of lineation clearly and succinctly in the brief Introduction.

Actors and directors frequently feel that modern editions over-punctuate, inhibiting the fluid delivery of the verse. ${ }^{59}$ It is thus tempting, in preparing an edition for performance, to strip back punctuation, basing it on the more sparsely punctuated early printed Quartos (when they exist). However, when editing a series, this can create inconsistency. Whilst in the case of Hamlet, the punctuation could be based on that of the very lightly punctuated Q2 (although this might, in places, be confusing, since whole speeches are punctuated as single sentences), The Winter's Tale could not be so repunctuated as it did not have a Quarto manifestation. The only surviving text of The Winter's Tale, published in the Folio, is thought, moreover, to have been repunctuated by the scribe Ralph Crane, who copied the text prior to its printing. ${ }^{60}$ Crane has a name for adding significantly to the punctuation of his copy text. ${ }^{61}$ The editions therefore 
adhere to the Arden 3 punctuation, but a note in the introduction explains this, making clear that "Actors are not obliged to follow the punctuation of the text in delivery. They may find that it is sometimes better to phrase according to the metre." 62

The glosses provided on the right-hand pages are, unlike some of those in scholarly texts, as short and simple as possible. The editions also gloss more words than most scholarly editions, providing a definition for any word that a modern actor might have difficulty understanding. Textual variants are also immediately apparent to the reader, though they are limited to those that offer the actor a genuine choice in performance, not those widely acknowledged to constitute an error.

In terms of metre and scansion, whilst Shakespeare's basic metre is iambic pentameter, his metrical line admits a number of variations, particularly as his career progresses and his poetry becomes more experimental. He has recourse to the trochee, the spondee and the anapest. The Performance editions do not seek to alert the user to each metrical variation: this is, in many cases, subjective. But when the metrical structure suggests that a word might be pronounced differently from its usual sound in present-day speech, either requiring eliding or expanding in order to fit with the metre, or when a line has more or less than ten syllables, the editions provide a note in order to help an actor to scan the line. The aim is, as stated in the Series Introduction, to "inform and assist rather than to dictate, and the pronunciation of words is, of course, a matter of individual choice". ${ }^{63}$ Where a line is metrically short, the editions provide a note, but do not insist that any particular delivery is implied by such a structure. ${ }^{64}$ The prefatory matter to the editions also contains a section entitled "A Note on Metre", which explains the common variations to the iambic pentameter, including the trochee, spondee, anapest, quartus paeon, hexameter, "headless" line, "broken-backed" line and feminine or "triple" ending. ${ }^{.5}$

In addition to words for which the metrical structure suggests a particular and unusual pronunciation, there are, inevitably, other words in the canon that have disappeared from common use. There are also a number of proper nouns - character names, place names and names of mythological figures - that actors may struggle to pronounce. ${ }^{66}$ The Performance editions provide a pronunciation guide to all character names in the "Dramatis Personae" and detail the pronunciation of recurring place names in the Introduction to each edition. Each edition also contains a list of "Key Figures of Classical Mythology" in the prefatory material; that, too, includes the pronunciation of names.

39 As discussed above, all of the directors and actors interviewed by this author for Shakespeare Bulletin expressed an interest in Shakespeare's use of his source material. As Gregory Doran indicates, if he wants to explore a particular source, he is more than capable of accessing the original, and frequently does. ${ }^{67}$ It is not the remit of the Performance editions to provide extracts from sources or extensive details of Shakespeare's treatment of them. However, where a character refers to an event, the source of which lies in another literary work, the Performance editions provide an indication of this source in a facing-page note..$^{68}$ The Introduction to each edition also provides a brief account of the key sources, directing the user to the Arden 3 editions for more extensive details. However, it also provides a caveat to actors:

It can be misleading for an actor to explore the source material for a text as a means of discovering more about a character, particularly in the case of historical figures: an attempt to play Shakespeare's Richard III as though the play were a 
documentary about the historical Richard III, for example, is likely to produce contradictory and undramatic results. ${ }^{69}$ becoming bulky. The editors have thus been selective about what has been included in the introductions, attempting to work out what actors and directors want to have to hand in a rehearsal room and what they can quite easily do in terms of research at home. The Series Introduction, which prefaces each edition, aims to be is short and informative, containing notes on editorial principals, which make clear the system of notation and decisions about lineation and punctuation. The introduction to each play contains enough material about the variant texts to make the notes on textual variants accessible. Thereafter the material is confined to areas that are key to an actor's interpretation of a role - the use of verse and prose in the play, the presence of metres other than iambic pentameter and significant use of personal pronouns. The issue of whether or not a character speaks in verse or prose is often seen as fundamental to characterization. Theatre practitioners often cite the move from verse to prose or vice versa in a scene as containing "hints to an actor"; ${ }^{70}$ which "highlight changes of intensity within scenes, and reflect in structure different kinds of content". ${ }^{71}$ Each edition provides details of which characters habitually use either verse or prose, and where key shifts occur. These shifts are also marked in the editions as a facing page note. In terms of the presence of other metres, such instances are rare in Hamlet, and are mostly confined to songs and rhymes. However, in a play like A Midsummer Night's Dream, the Introduction to the Performance edition notes the use of trochaic tetrameter (mostly catalectic) and anapestic dimeter for magical characters (notably Puck, Oberon and the fairies) and a variety of metres (alexandrines, iambic pentameter and ballad metre) used in the play-within-a-play, "Pyramus and Thisbe." The presence of metres other than iambic pentameter is also noted in the text as a facing page note. As Penelope Freedman discusses in detail in Power and Passion in Shakespeare's Pronouns, a character's use of a particular pronoun at a particular moment in a play is "an essential note in the voice of the speaker [...] motivated partly by genre, but also by setting, situation, character, relationship, mood, tenor and rhetoric". ${ }^{72}$ The Series Introduction to the Performance editions explain the distinction between "you" and "thou", something of which many actors remain unaware, ${ }^{73}$ alerting the user to the "special" use of "thou", often as a marker either of affection or of conflict. ${ }^{74}$ Each edition contains introductory material on significant uses of personal pronouns as markers of intimacy or distance, infantilisation or affection.

The Arden Performance editions were launched at RADA (The Royal Academy of Dramatic Art) in London in November 2017. The next phase in the life of these editions will be a more detailed practice-as-research one, exploring their impact and reach within the theatrical industry, in the UK, US and beyond, and the extent to which they prove transformative within a rehearsal-room context. This exploration will also consider the extent to which such a project is specific to the Shakespearean canon, or whether the sorts of interventions made by this series might be extended into editions of other Early Modern dramatists. It is inevitable that as editors work with different plays, new questions will emerge about the best way to handle metrical irregularity, metrical ambiguity, textual variants and other textual issues, and it is expected, and indeed hoped, that the series will evolve in response to the challenges encountered by new editors, and the feedback from users of the texts. But, of course, there can never be a "perfect" performance edition. 


\section{NOTES}

1. For example: "As it was Plaide by the Right Honourable the Earle of Darbie, Earle of Pembroke, and Earl of Sussex their Seruants" (The Most Lamentable Tragedie of Titus Andronicus, 1594, title page).

2. See Lois Potter, The Life of William Shakespeare: A Critical Biography, Oxford, 2012, p. 369.

3. These include the Hamlet quartos of 1676, 1683 and 1695, based on the Davenant/ Betterton text.

4. Michael Dobson, "Shakespeare on the Page and Stage", in The Cambridge Companion to Shakespeare, eds. Margreta de Grazia and Stanley Wells, Cambridge, 2001, p. 239.

5. Peter Holland, "Theatre Editions" in Shakespeare and Textual Studies, eds. Margaret Jane Kidnie and Sonia Massai, Cambridge, 2015, p. 235.

6. Bernice W. Kilman, "Explicit Stage Directions (Especially Graphics) in Hamlet", in Stage Directions in Hamlet: New Essays and New Directions, ed. Hardin L. Aasand, Madison, 2003, p. 85.

7. William Shakespeare, Hamlet, Prince of Denmark a Tragedy: As it is now Acted by his Majesty's Servants, London, 1718, sig. A2v.

8. Holland, “Theatre Editions", p. 234.

9. William Shakespeare, Bell's Edition of Shakespeare's Plays, London, 1774, Title page.

10. Francis Gentleman, Introduction to Shakespeare's Plays, containing an essay on oratory, London, 1773 , p. 5.

11. Idem, p. 6-7.

12. Charles H. Shattuck, The Shakespeare Promptbooks, Chicago, 1965 , p. 8.

13. Kemble's acting editions of Hamlet were published in 1796, 1797, 1800, 1804, 1808, 1811 and 1814 (Charles H. Shattuck, ed., John Philip Kemble Promptbooks, Virginia, 1974, Vol. 2 p. ii).

14. William Shakespeare, Hamlet, a Tragedy in Five Acts, No. 25 Cumberland's British Theatre, London, 1826.

15. Shakespeare's Tragedy or Hamlet, Prince of Denmark, Arranged for Representation at the Princess's Theatre, London, 1859.

16. Hamlet, 1826, p. 14 and Hamlet, 1859, p. iii.

17. Shattuck, The Shakespeare Promptbooks, p. 8.

18. Frank A. Marshall, "Preface", The Works of Shakespeare, ed. Henry Irving and Frank A. Marshall, Vol. 1, London, 1895, p. vi.

19. Idem, p. v.

20. Idem, p. vi.

21. Idem, p. vi-vii.

22. "probation" (1.1.155), “complexion" (1.4.25), “malefactions" (2.2.587), “determination" (3.1.166), "addition" (4.4.17).

23. Numerous examples can be found merely through an examination of the first two scenes of the play: "apparition" (1.1.26; 1.2.220), "eruption" (1.1.66), "discretion" (1.2.5), "proportions" (1.2.32), "petition” (1.2. 59), "suspiration" (1.2.79), “obligation" (1.2.91), “disposition” (1.2.169), "admiration" (1.2.191).

24. Marshall, "Preface", p. vi.

25. Ibid.

26. William Shakespeare, King Lear, ed. Stephen Unwin, London, 2002; William Shakespeare, Romeo and Juliet, ed. Stephen Unwin and Michael Cronin, London, 2003; William Shakespeare, Twelfth Night, ed. Stephen Unwin, London, 2004; William Shakespeare, Hamlet, ed. Stephen Unwin, London, 2005.

27. Holland, “Theatre Editions", p. 237. 
28. Josie Rourke, "A note on the text", in Coriolanus by William Shakespeare, eds. Rob Hastie and Josie Rourke, London, 2014, preface, n.p..

29. William Shakespeare, Hamlet, French's Acting Edition, London, 1964, preface, n.p..

30. Idem, p. 1.

31. Idem, p. v.

32. Holland, "Theatre Editions", p. 247.

33. Peter Holland, "Film Editing", in Shakespeare Performed: Essays in Honor of R. A. Foakes, ed. Grave Ioppolo, Newark, 2000, p. 275-276.

34. James Hayes, Shouting in the Evenings, London, 2016, p. 111.

35. Glyn Idris Jones, No Official Umbrella, Crete, 2008, p. 176.

36. Stanley Wells, Shakespeare on Page and Stage, Oxford, 2016, p. 372.

37. Abigail Rokison-Woodall, "Interviews with theatre practitioners about texts for performance", Shakespeare Bulletin, 34.1, 2016, 47-68, p. 57.

38. Abigail Rokison, Shakespearean Verse Speaking, Cambridge, 2009, p. 3-4; 66.

39. Peter Hall, Exposed by the Mask, London, 2000, p. 44.

40. Hall, op. cit., p. 55.

41. Patsy Rodenburg, Speaking Shakespeare, London, 2002, p. 97-98.

42. Stanley Wells, Gary Taylor et al. (eds.), The Oxford Shakespeare: The Complete Works, Oxford, 1986; Gary Taylor, John Jowett, Terri Bourus and Gabriel Egan (eds.), The New Oxford Shakespeare: The Complete Works, Oxford, 2016; Jonathan Bate and Eric Rasmussen (eds.), The RSC Shakespeare: William Shakespeare: Complete Works, Basingstoke, 2007.

43. This lineation can be found in Hamlet, eds. Ann Thompson and Neil Taylor, London, 2006, p. 182 and Hamlet: The Texts of 1603 and 1623, London, 2006, p. 194.

44. William Shakespeare, Hamlet, ed. Philip Edwards, Cambridge, 2003, p. 91.

45. These are described by Thompson and Taylor as "single-text, eclectic editions" (Thompson and Taylor, eds., Hamlet, p. 11).

46. Thompson and Taylor, eds., op. cit., p. 92.

47. Stanley Wells, Shakespeare on Page and Stage, Oxford, 2016, p. 373.

48. Rokison-Woodall, art.cit., p. 48, 59, 56.

49. Rokison-Woodall, art.cit., p. 53.

50. Rokison-Woodall, art.cit., p. 63.

51. Ibid.

52. Rokison-Woodall, art.cit., p. 65.

53. Thompson and Taylor, eds., Hamlet: The Texts of 1603 and 1623.

54. George Steevens, ed., The Plays of William Shakespeare, 15 vols., London, 1793.

55. George T. Wright refers to such instances as "squinting" lines (George T. Wright, Shakespeare's Metrical Art, Berkeley, 1998, p. 103).

56. Such a possibility was first suggested by E. A. Abbott in A Shakespearian Grammar, London, 1869, p. 426-427.

57. Rokison, Verse Speaking, p. 105.

58. Idem, p. 311.

59. Idem, p. 69-70.

60. J. H. P. Pafford, ed., The Winter's Tale, London, 1963, p. xviii-xix.

61. Paul Werstine asserts of Crane that "The more plays he copies, the more punctuation he appears to add" (Paul Werstine, "Ralph Crane and Edward Knight: professional scribe and King's Men's bookkeeper", in M. Kidnie and S. Massai, eds., Shakespeare and Textual Studies, Cambridge, 2015, p. 28).

62. Abigail Rokison-Woodall, ed., Arden Performance Editions: Hamlet, London, 2017, p. x.

63. Idem, p. xiii.

64. See Rokison, Shakespearean Verse Speaking, p. 325-6. 
65. Rokison-Woodall, ed., Hamlet, p. xxiii-xxviii.

66. Dale F. Coye asserts that "This is something which actors obviously must struggle with" (Pronouncing Shakespeare's Words: A Guide from A to Zounds, New York, 1998, p. ix).

67.

68. Rokison-Woodall, ed., Hamlet, p. 139.

69. Idem, p. $\mathrm{xx}$

70. John Barton, Playing Shakespeare, London, 1984, p. 70.

71. Rodenburg, p. 161.

72. Penelope Freedman, Power and Passion in Shakespeare's Pronouns, Aldershot, 2007, p. 259.

73. Idem, Preface.

74. Rokison-Woodall, ed., Hamlet, p. xvii.

\section{ABSTRACTS}

In the wake of the publication of the new Arden Performance editions of Shakespeare, launched in 2017, this paper examines the history of the use of Acting editions and scholarly edited texts in the preparation of theatrical productions in the professional theatre. It argues that the time is ripe to reconceive the nature of an Acting edition, and to consider what actors and directors need from a rehearsal room text.

À la suite des nouvelles éditions des pièces de Shakespeare dans la série Arden Performance, lancée en 2017, cet article s'intéresse à l'histoire de l'usage des éditions pour acteurs et des éditions scientifiques des textes de théâtre au moment de la préparation des mises en scène professionnelles au théâtre. On y soutient qu'il est temps de reconsidérer la nature d'une édition pour acteurs et d'envisager ce que les acteurs et les metteurs en scène ont besoin de trouver dans un texte utilisé pour les répétitions.

\section{INDEX}

Mots-clés: Shakespeare, Édition, Hamlet, Acteurs, représentation théâtrale, Metteurs en scène Keywords: Shakespeare, Editing, Performance, Hamlet, Actors, Directors 